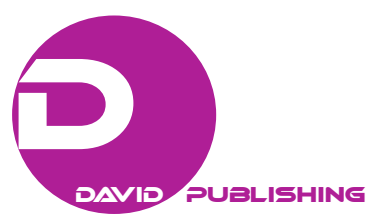

\title{
Iranian Nuclear Program and Turkey’s Nuclear Nonproliferation Policy
}

\author{
Özum Sezin Uzun \\ İstanbul Aydın University, İstanbul, Turkey
}

\begin{abstract}
Turkey is a member of several international nonproliferation treaties and organizations. It has supported to prevent proliferation of nuclear weapons and furthermore suggested to establish a nuclear-weapon free zone in the Middle East. In contrast to its nonproliferation policies, it is hosting US tactical nuclear warheads in its own territory. In addition, Turkey's positive stance towards Iranian nuclear program was questioned. Despite the West's warnings and concerns over the Iranian nuclear program, Turkey has supported Iran's right to have a peaceful nuclear program as suggested in the Nonproliferation Treaty. It also opposed to further economic sanctions and military intervention against Iran and endorsed diplomatic solution as the only viable option for convincing Iran to respond fully to the concerns of the international community. Therefore, Turkey welcomed the Geneva Agreement reached by Iran and P5+1. This article argues that the current uncertainties about the Geneva Accord and the comprehensive treaty necessitates Turkey to revise its nonproliferation policies, which should be based on the norm of nonproliferation, rather than the non-use and deterrence norms, in order to suggest long-term and permanent solution to the proliferation of nuclear weapons.
\end{abstract}

Keywords: nuclear weapons, Iran's nuclear program, Geneva Accord, Turkey’s nonproliferation

\section{Introduction}

In November 2013, it is declared that Iran and P5+1 reached an interim agreement, by which Iran agreed to freeze some key activities in its nuclear program in return for 6 months some sanctions relief. Regarding the fluctuations during the negotiation process and the several UN resolutions over the last decade, the latest agreement was welcomed and raised optimism for the future of nonproliferation regime. However, it also includes the concerns whether the interim agreement will not be terminated by a comprehensive and permanent agreement. In the worst scenario, Iran would be closer to acquire nuclear weapons and the nonproliferation regime would be at great risk. It is obvious that a nuclear Iran would either increase the risk of a new regional war or trigger the emergence of new proliferators. Under this circumstance, Turkey would be one of the most negatively affected countries by a nuclear Iran. Regarding the risks and opportunities with the interim agreement on Iranian nuclear program, what should Turkey's nuclear nonproliferation policies be? Should Turkey continue to rely on the deterrence norm of nuclear nonproliferation regime or should it actively involve themselves in changing paradigms in the nonproliferation efforts? Within this framework, this article will firstly analyze Turkey's policies towards Iranian nuclear program, and then analyze Turkey's nuclear nonproliferation policies.

Özum Sezin Uzun, Assist. Prof. Dr., Department of Political Science and International Relations, İstanbul Aydın University. 


\section{Iranian Nuclear Program: Threat or Not?}

Turkey's policy towards the Iranian nuclear program has been based on two principles. Firstly, since the Non Proliferation Treaty (NPT) does not ban civilian nuclear programs, Turkey acknowledges that Iran has the right to use nuclear energy for civilian purposes. More importantly, Turkey believed in Iran's claim that its current nuclear program is intended for civilian purposes. Turkey's President Erdoğan, who was Prime Minister at that time, stated "I have talked to key Iranian officials about the nuclear issue. I'm convinced that Iran is only developing nuclear energy, not weapons” (Erdoğan: Nükleer Enerji Çalışması Barış̧̧ı, 2009). Turkey has also called on Iran to implement transparency measures and cooperate with the International Atomic Energy Agency (IAEA). Namık Tan, who was spokesperson for Turkey's Minister of Foreign Affairs, for instance, explained that "We do not disregard the fact that Iran should engage in full and transparent cooperation with the IAEA [to] take additional confidence-building measures to prove that its nuclear program is exclusively designed for peaceful purposes" (Ankara Shares International Concerns over Iran, 2006). Abdullah Gül, who was Minister of Foreign Affairs at that time, also mentioned "As a signatory of the Nuclear Nonproliferation Treaty, Iran has $100 \%$ responsibility to show transparency on the nuclear issue" (Gül: Turkey against WMDs in Mideast, 2006). Regarding the statements of Turkish officials, it seems that Turkey did not perceive any threat from Iranian nuclear program. However, it does not mean that Turkey would not perceive a threat from a nuclear Iran. Therefore, Turkey pays attention not to appear to support the Iranian nuclear program unconditionally, while supporting Iranian nuclear program for civilian purposes. It repeated calls for Iran to be more transparent and to continue to work with the IAEA in order to minimize the risk of facing with an Iranian nuclear-weapon program. Turkey stressed the importance of Iran's nuclear program remaining within the limits of the NPT.

Secondly, Turkey supported a diplomatic solution is the only viable option for convincing Iran to respond fully to the concerns of the international community. The major motivation of Turkey behind the endorsement of diplomatic solution was certainly its security concerns. From Turkey's perspective, any additional war in the Middle East would have devastating results in political, economic and humanitarian means. Furthermore, any peaceful solution would mean the elimination or at least the reduction of a nuclear Iran risk. A broad consensus has developed among Turkish elites that any military action against Iran will have catastrophic consequences; therefore Turkish officials have taken every opportunity to express its opposition to the possibility of a military strike. Erdoğan, for instance, criticized the possibility, observing that even though the Iraq War had accomplished nothing, the world was discussing using the same tactics against Iran (Albayrak, 2009). He also underlined that "We do not want any strikes against Iran's nuclear facilities. This would be a grave mistake". (Turkey's Prime Minister Warns Against Attack on Iran's Nuclear Facilities, 2009). Turkey opposed not only military measures, but also economic sanctions, because it had already faced with the challenges of the sanctions in the case of Iraq (Üstün, 2010). In line with these policies, Turkey demonstrated its willingness to take an active role to find a diplomatic solution for Iranian nuclear program, taking an initiative with Brazil, known as the Tehran Declaration in 2010.

\section{Turkey: Would Take an International Role in Nonproliferation?}

Iranian nuclear program was not only perceived by Turkish decision-makers as a means to raise security concerns of Turkey, but also as an opportunity to be used to take an active role in nonproliferation efforts at the international level. Its initiative with Brazil was in line with the latter perspective. 
Turkey and Brazil intervened to negotiation process as a broker and their foreign ministers signed Tehran Declaration on May 17, 2010 with their Iranian counterparts. According to Declaration, Iran agreed to send some $1200 \mathrm{~kg}$ of its $3.5 \%$ enriched uranium over to Turkey in exchange for a total of $120 \mathrm{~kg}$ of $19.75 \%$ enriched uranium fuel elements for the TRR in return from the so-called Vienna Group, comprising the IAEA, USA, Russia and France (Salehi: Acceptance of Turkey-Brazil Offer Signifies Iran's Good Will, 2010). The Declaration emphasized two main principles: First, Turkey, Brazil and Iran reiterated their commitment to the NPT and "the rights of all state parties to develop, research, production and use of nuclear energy - as well as nuclear fuel cycle including enrichment activities-for peaceful purposes without discrimination"; and second, the declaration commented on the strong conviction of the three countries:

the nuclear fuel exchange is a starting point to begin cooperation and a positive constructive move forward among nations. Such a move should lead to a positive interaction and cooperation in the field of peaceful nuclear activities replacing and avoiding all kinds of confrontation through refraining from measures, actions and rhetorical statements that would jeopardize Iran's rights and obligations under the NPT. (17.05.2010 Joint Declaration of the Ministers of Foreign Affairs of Turkey, Iran and Brazil)

From the Turkish and Brazilian perspectives, the deal represented an important achievement towards promoting a diplomatic solution to the ongoing debate over Iran's nuclear program. In addition, both Turkish and Iranian officials perceived the agreement as a sign of Iran's good will, which would be the first step to resolving the problem through diplomatic means. Turkish Foreign Minister Davutoğlu commented, "The swap deal shows that Tehran wants to open a constructive path. There is no more ground for new sanctions and pressures" (Schleifer, 2010). The foreign ministers of Turkey and Brazil thus sent a letter to the UN Security Council declaring, "Brazil and Turkey are convinced that it is time to give a chance for negotiations and to avoid measures that are detrimental to a peaceful solution of this matter" (Brazil, Turkey Urge Delay in UN Sanctions Vote on Iran, 2010). However, the nuclear fuel swap agreement did not convince the West. Catherine Ashton, a spokeswoman for the European Union's foreign policy stated,

If Iran has now accepted the IAEA proposal, this is welcome, but it [the nuclear fuel swap deal] does not solve the fundamental problem, which is that the international community has serious concerns about the peaceful intention of the Iran nuclear program. (Schleifer, 2010)

European concerns were mainly about the continuation of Iran's enrichment activities. The P5+1 voiced its deep concern over the nuclear fuel swap, which it perceived as an attempt by Iran to sidestep further sanctions without actually taking steps to address international concerns about its nuclear program (Text: Powers Dismiss Iran Fuel Offer Before UN Vote, 2010). Regarding the P5+1 criticism, Turkey's Minister of Foreign Affairs, Davutoğlu, stated that,

Turkey's and Brazil's role was to negotiate the swap deal to build confidence between sides. The enrichment activity of Iran is a topic of the negotiations between P5+1 and Iran. Turkey and Brazil are not in a position to negotiate the suspension of enrichment activities on behalf of P5+1 or the IAEA. (Dışşşleri Bakanı Davutoğlu'nun İran ile Varılan Nükleer Uzlaşı ile Güncel Dış Politika Gelişmeleri Hakkında Basın Toplantısı Metni, 2010)

As seen, Turkey did not attempt to take a mediator role in the negotiations over Iranian nuclear program. It endeavored to build confidence between sides, but did not succeed. The reasons of Turkey's failure lie on its insufficient capacity to successfully solve international problems and the negative stances of both sides to Turkey's involvement. As a result, US-led further sanctions were approved by the UN Resolution 1929, which 
demanded Iran to suspend enrichment activities. It cited the risk of proliferation posed by the program and noted that Iran had failed to cooperate with the IAEA. The Resolution dictated that all states work to prevent the supply, sale or transfer to Iran of battle tanks, armored combat vehicles, large caliber artillery systems, combat aircraft, attack helicopters, warships, missiles or missile systems. It also asked states to take all necessary measures to prevent the transfer of technology or technical assistance related to ballistic missiles capable of delivering nuclear weapons to Iran. In addition, the resolution contained provisions blocking Iran's use of the international financial system, particularly its banks, which would be used to fund proliferation activities. With the UN Resolution 1929, the initiative of Turkey and Brazil was negated (UN Security Council, Resolution, 1929).

\section{Instead of a Conclusion: The Necessity to Rethink Turkey's Nonproliferation Policies After the Geneva Accord}

After the failure of the Geneva Accord, Turkey continued to follow attentive the negotiation process over Iranian nuclear program without attempting to take an active role. When the P5+1 and Iran reached an agreement and signed the Geneva Accord, Turkey welcomed and defined it as "the first concrete positive development since the Tehran Declaration in 2010" (Turkey Welcomes Iran Nuclear Agreement, 2003). Turkey's positive stance towards the Geneva Accord is primarily based on its security considerations. As previously mentioned, a possible nuclear Iran has always been the security concern of Turkey. If the Geneva Accord will lead to a comprehensive agreement, it would lead to a satisfactory outcome for Turkey's security, preventing Iran from becoming the nuclear proliferation. Under the current uncertainties whether the interim agreement will turn to a comprehensive agreement or the comprehensive agreement would be permanent or not, the reality of nuclear proliferation issue is seen more serious and urgent problem to be addressed. Therefore, international nonproliferation efforts and Turkey's nonproliferation policies should critically be evaluated, emphasizing the importance of the nuclear nonproliferation norm-setting process.

The international nuclear nonproliferation efforts exist for 40 years and include a number of multilateral mechanisms. However, there are still two significant challenges against the current nonproliferation regime. The first challenge is the ineffective institutional mechanism, including nuclear nonproliferation treaties and organizations. The discriminative treatment of the NPT, for instance, is one of the major challenges. It creates a dichotomy between nuclear weapon states and non-nuclear weapon states, taking different measures against each of their proliferation attempts. Therefore, the effectiveness of NPT should critically be evaluated taking into account the newly emergent challenges in the post-Cold War era. In this respect, the Review Conference of the NPT in 2015 should provide a platform to discuss the NPT-induced problems and create a ground to examine the prospect of ending indefinite extension of the treaty. The inefficient measures of the IAEA to enforce nonproliferation policies also create significant impediments. Therefore, setting nonproliferation norm should be started from a scratch, providing rigid rules and enforcement mechanism for all states.

The second challenge is the continuation of states' motivations to acquire nuclear weapons. It seems that perceiving nuclear weapons as a political tool now represents one of the most serious challenges for the international nuclear nonproliferation regime. Although the weapons proliferation is a complex phenomenon to be explained fully by any single approach, the political, social and cultural meanings have impact on acquiring nuclear weapons. Eyre and Suchman (1996), for instance, argue that socially constructed meanings that have associated with weapons are the main factors that have worked for the proliferation (pp. 86-87). According to 
them, linking conventional weapons with sovereign status as a nation, with modernization and social legitimacy have caused to the proliferation. Scott Sagan as well argues that the determinant force behind the proliferation of nuclear weapons is more than for national security. According to him, nuclear weapons serve both as the political tool in internal bureaucratic struggles and as international normative symbols of modernity and identity (Sagan, 1996/97, p. 55). In addition, acquiring a nuclear weapon has been associated with the status of a "superpower" or "regional power." Therefore, setting nonproliferation norm is quite important to terminate the political meaning of nuclear weapons in international politics.

Regarding these challenges, the Iranian nuclear program demonstrates the necessity to focus on nonproliferation norm setting. Since Turkey would be one of the mostly affected countries from a nuclear Iran, it is expected to take an active role in preventing nuclear proliferation in its neighbors. In that respect, Turkey's nonproliferation policies should be re-examined. Like international nonproliferation regime, Turkey's policy primarily based on non-use and deterrence norms of nuclear weapons. However, these norms do not address adequately to the proliferation problems.

Although Turkey is a member of several nonproliferation treaties, many Turkish elites from both political and military circles believe that nuclear weapons have military and political meanings. According to them, nuclear weapons would serve for increasing both hard and soft power of Turkey. In that respect, hosting US nuclear weapons in Turkey's territory is commonly viewed as providing deterrent power to Turkey in a region where countries that have nuclear capability or motivation geographically surround it. What is important to answer is do US nuclear warheads really provide deterrent power to Turkey against its foes.

The central idea about the non-use of nuclear weapons lies on two basic assumptions. The first is identifying nuclear weapons as "weapons of mass destruction", which delegitimizes them as weapons of war. However, the introduction of tactical nuclear weapons has weakened the logic of non-use of nuclear weapons. Since tactical nuclear weapons reduced the disproportionate destructive power of nuclear weapons with the advanced technology, the risk of their use has been increased. The less destructive power of tactical nuclear weapons made them to be accepted usable. Therefore, the challenge to the international nuclear nonproliferation regime arises not only from the failure or weaknesses of normative prohibitions, but also from the continuation of the role of nuclear weapons in the military of the nuclear-weapon states. The second is based on the norm of deterrence, which implies that the outcome of the use of nuclear weapons would be so extreme that prevent actors from taking such a decision. However, newly emerging threats, which also increase the risk of a nuclear attack, jeopardize deterrence and non-use norms of international nonproliferation regime. One of the factors that increased the risk of a nuclear attack is the emergence of non-state actors as a potential new user of nuclear weapons. Taking Turkey's geopolitics into account, it is unclear whether the US nuclear warheads would deter any attempt of first use of nuclear weapons by the terrorist organizations against Turkey. Even though the usage of nuclear weapons by the non-state actors is currently seen less-likely, it is assumed that "more nuclear materials are being produced, more knowledge relevant to the construction of nuclear weapons is being dispersed, and terrorist organizations are becoming more interested in acquiring nuclear capabilities" (Doyle, 2013, p. 16). Furthermore, the existence of nuclear weapons, either strategic or tactical, triggers the security dilemma, which would inevitably end with nuclear proliferation. Therefore, the ultimate objective of Turkey should be to eliminate stockpiles of nuclear weapons and materials in its region, leading an initiative to set nonproliferation norms at both international and regional levels. Within this framework, its participation to the Nonproliferation and Disarmament Initiative (NPDI) is admirable, but not sufficient. 
Turkey is expected to take and lead more active role in setting nonproliferation norm of nuclear weapons. Last but not least, hosting nuclear weapons in Turkey, which refers to the acceptance of military and political role of these weapons, does certainly contradict with its current nonproliferation policies.

\section{References}

Albayrak, H. (2009, September 28). Türkiye Iran'ı Satmıyor. Yeni Şafak.

Ankara Shares International Concerns over Iran. (2006, February 3). Hürriyet Daily News.

Brazil, Turkey Urge Delay in UN Sanctions Vote on Iran. (2010). BBC. Retrieved May 19, 2010, from http://www.bbc.co.uk/news/10126252

Dışişleri Bakanı Davutoğlu'nun İran ile Varılan Nükleer Uzlaşı ile Güncel Dış Politika Gelişmeleri Hakkında Basın Toplantısı Metni. (May 19, 2010). Republic of Turkey Ministry of Foreign Affairs. Retrieved June 8, 2011, from http://www.mfa.gov.tr/bakan-davutoglu_nun-iran-ile-varilan-nukleer-uzlasi-ile-guncel-dis-politika-gelismeleri-hakkinda-basi n-toplantisi-metni.tr.mfa

Doyle, J. E. (2013). Why eliminate nuclear weapons? Survival: Global politics and strategy, 55(1), 7-34.

Erdoğan: Nükleer Enerji Çalışması Barışçı. (2009, October 27). Radikal.

Eyre, D. P., \& Suchman, M. C. (1996). Status, norms and the proliferation of conventional weapons: Institutional theory approach. In P. J. Katzenstein (Ed.), The culture of national security: Norms and identity in world politics (pp. 79-113). New York: Columbia University Press.

Gül: Turkey against WMDs in Mideast. (2006, May 3). Hürriyet Daily News.

Sagan, S. D. (1996/97, Winter). Why do states build nuclear weapons?: Three models in search of a bomb. International Security, 21(3), 54-86.

Salehi: Acceptance of Turkey-Brazil offer signifies Iran's good will. (2010, May 17). Fars News Agency.

Schleifer, Y. (2010, May 22). Turkey's approach to Iran a calculated gamble. Iran Review. Retrieved May 8, 2011, from http://www.iranreview.org/content/Documents/Turkey_s_Approach_to_Iran_a_Calculated_Gamble.htm

Text: Powers Dismiss Iran Fuel Offer Before UN Vote. (2010, June 9). Reuters. Retrieved June 9, 2010, from http://www.reuters.com/article/2010/06/09/us-nuclear-iran-response-text-idUSTRE6582W120100609

Turkey Welcomes Iran Nuclear Agreement. (2013, November 24). Today's Zaman.

Turkey's Prime Minister Warns Against Attack on Iran's Nuclear Facilities. (2009, September 30). Inside Iran. Retrieved December 25, 2009, from http://www.insideiran.org/media-analysis/turkey\%e2\%80\%99s-prime-minister-warns-against-attack-on-iran $\%$ e2\%80\%99s-n uclear-facilities/

UN Security Council, Resolution 1929, S/RES/1929. (2010, June 9).

Üstün, K. (2010). Turkey’s Iran policy: Between diplomacy and sanctions. Insight Turkey, 12(3), 19-26.

17.05.2010 Joint Declaration of the Ministers of Foreign Affairs of Turkey, Iran and Brazil. (2011). Republic of Turkey Ministry of Foreign Affairs. $\quad$ Retrieved $\quad$ June $\quad 8, \quad$ 2011, from http://www.mfa.gov.tr/17_05_2010-joint-declaration-of-the-ministers-of-foreign-affairs-of-turkey_-iran-and-brazil_.en.mfa 